\title{
Protection of Human Rights and Legal Interests by the European Convention in Russia and Germany
}

\author{
Anna Pushkina* \\ Siberian Federal University \\ 79 Svobodny, Krasnoyarsk, 660041, Russia
}

Received 13.04.2017, received in revised form 5.06.2017, accepted 9.06.2017

The European Convention on Human Rights (ECHR) is an international treaty aimed at protecting human rights and fundamental freedoms in Europe. The Convention came into force on 3 September 1953. All member states of the Council of Europe ratified the Convention, which established the European Court of Human Rights (ECtHR). The main purpose of this research is to demonstrate preventive mechanisms that the ECtHR can use in order to protect human rights and legitimate interests. Numerous works in the field show that any person whose rights have been violated by a state can submit a claim to the Court and count on its assistance. Firstly, the article discusses some judgements of the ECtHR against Germany and Russia. Secondly, the author outlines the conclusions of the Court in respect of these cases. In addition, the article illustrates the possibility of preventive protection by the ECtHR. Basically, the decisions of the Court stimulate positive changes in Russian and German legal frameworks and ensure proper implementation of human rights and legal interests. All in all, the European Court of Human Rights protects human rights not only in a repressive, but also in a preventive way.

Keywords: preventive protection of human rights, European Court of Human Rights.

DOI: 10.17516/1997-1370-0120.

Research area: law.

The story, which we would like to start our article with, happened on a cold January day. Irina Khrabrova was teaching, as usually, one of the classes in a gymnasium in Moscow. However, as the teacher said, one of the pupils behaved too incorrectly that day and she advised her to go to the dining room to calm down and drink some tea. The pupil, according to her mother's words, left the school without a coat, and walked a few hours in the cold so that she caught a cold as a result.
The mother complained to the director that the teacher violently insulted her daughter and drove her out into the street. On February 21, 2002, the director fired $\mathrm{K}$. due to the implementation of unacceptable methods for maintaining the discipline. Miss K. appealed to the Moscow court regarding her dismissal, which left the dismissal in force. Since appeals to higher courts did not bring any results in 2008, Miss K. appealed to the European Court of Human Rights, which

(C) Siberian Federal University. All rights reserved

* Corresponding author E-mail address: annetta_t@mail.ru 
got things going in an absolutely new way. The Court determined that the Moscow court had imposed the judgement without listening to the pupils of Ms. K.'s class, taking only the testimony of persons who had not witnessed the events, but testified against Khrabrova. Therefore, the Court determined violation of Ms. K's right for a fair and just trial. The Court compelled the Russian Federation to pay a compensation (Case of Khrabrova..., 2012). Therefore, the European Court of human Rights solves the problems of common people, if they were refused the state defense of their interests.

Let us note that since 2014 the European Convention on Human Rights has been operating in 47 states. It has been protecting and defending the rights of more than 800 million people. Though the protection does not remain only on paper. The Convention provides an opportunity to apply for protection in court in case of violation of the rights provided for by the Convention. However, national courts do not always take fair decisions, which allows citizens to apply to the European Court of Human Rights for fair protection.

At the beginning of the article we presented the situation when the rights of Khrabrova had been already violated and therefore she asked for protection from the European Court. Though, the ECtHR plays an important role also in preventive protecting the rights of citizens.

To support this thesis, let us present an example from German practice, the case of Boehmer v. Germany (Case of Böhmer..., 2001). In this case, the European Court of Human Rights explained to German courts that the cancellation of parole for preventive purposes under $\S 56 \mathrm{f}$ of the German Criminal Code without a valid court decision on a new crime is possible only under exceptional circumstances. In Germany, the interpretation of the Constitutional Court was widely applied, which considered that cancellation of parole is also possible on the basis of the court's own assumptions about the commission of a crime without a new court judgement.

Finally, in the 1990s, changes were made to the German Code of Criminal Procedure and the word "accused" was replaced by the person who committed a crime ( $\S 98 \mathrm{a}$ para 1 sentence 2; para 1 Number 1-3, para 2 sentence 2; 163d para 1 sentence 2; 163e para 1 sentence 2, 3; 163f para 1 sentences 2, 3; Code of Criminal Procedure). These changes contributed to the protection of the rights of many individuals in Germany while they prevented the illegal cancellation of the parole.

Subsequently, the European Court of Human Rights made similar conclusions in the case of Sergei Kuznetsov v. Russia (Case of Sergey Kuznetsov..., 2008). In particular, the reason for the Court's concern is that the first mention of the alleged discrepancy between the picket's objectives and the contents of the disseminated materials was contained in a letter from the deputy chairman of the Sverdlovsk Regional Court, which was an official report to the chairman criticizing the Regional Court in the disseminated publication. The wording that the deputy chairman used in his letter, for example the statement that the picketers "committed an administrative offense", predetermined the assessment of the facts of the competent court and expressed the opinion that the Applicant was guilty even before the guilt was proven in accordance with the law.

The history of the Convention knows a lot of major legislative and constitutional reforms aimed at ensuring its implementation in European countries. However, in practice, the need to amend legislation in connection with the implementation of judgments of the European Court does not arise as often as it may seem, while the constitutions and laws of the participating states are rarely in an open conflict with the Convention. Violations 
of the latter are usually associated with problems that lie in the sphere of law enforcement practice of state bodies, primarily, courts. Therefore, it is the change in this practice that is the most frequent general measure used to prevent new violations of the Convention. But even in cases where the reason for the violation of the Convention is the domestic law, the judges of the respondent state are the key players in the implementation of the decisions of the European Court of Justice, which often simply refuse to apply this law, relying directly on the norms of the Convention and the decisions of the European Court.

It is especially worth noting the situations when the decisions of the European Court of Human Rights result not in the change of legislation, but in the real protection of the rights and freedoms of citizens.

Thus, in the cases of the "Moscow branch of the Salvation Army v. the Russian Federation", "Religious Community of Jehovah's Witnesses in Moscow v. the Russian Federation", "Scientology Church of Moscow v. the Russian Federation", the European Court noted that the grounds for refusing to re-register the applicant community, which the Main Directorate of the Ministry of Justice of the Russian Federation for Moscow referred to and which the Moscow courts agreed with, were illegal, the European Court comes to the conclusion that when refusing Jehovah's Witnesses in Moscow in re-registration the state bodies in Moscow, acted in bad faith and did not fulfill their duty to preserve neutrality and impartiality towards a religious association. The result of these decisions was not only the protection of the rights of religious associations, but also the protection of the freedom of conscience and religion of persons professing this religion. Their right was backed up by additional guarantees, in particular, the ministers of this church were now not obliged to testify, if the circumstances of the case became known to them in confession.
As the argument, the court noted that the freedom to manifest one's religion or beliefs in accordance with Article 9 of the European Convention on the Protection of Human Rights and Fundamental Freedoms can be only subject to restrictions that are prescribed by law and are necessary in a democratic society in the interests of public safety, to protect public order, health or morality, or to protect the rights and freedoms of others.

While the "freedom of religion is primarily a matter of conscience for everyone, it also implies the freedom to 'profess one's religion' both individually and in cooperation with others, publicly or privately. Since religious communities traditionally exist in the form of organized structures, Article 9 of the Convention should be interpreted in the light of Article 11 of the Convention, which protects freedom of association with others from undue interference by the state".

The duty of the state to preserve neutrality and impartiality does not allow it to assess the legitimacy of religious beliefs or ways of expressing them. Consequently, the legal norms provide the state with narrow limits of discretion, and it must have serious and compelling reasons for interfering with the choices that citizens can make basing on the desire to follow religious norms of conduct. Intervention may be justified within the meaning of Paragraph 2 Article 9 of the European Convention if such a choice is contrary to the most important legal principles underlying the European Convention, such as in the case of polygamous marriages or marriages with minors, or if such choice is imposed on the religious people by the use of force or coercion, against their will.

Thus, the examples presented show that the European Court of Human Rights acts not only repressively, but also preventively. After all, as a result of its decisions, the legislation is 
changing, and by protecting the rights of some, it thereby provides the necessary guarantees for the rights of others. Unfortunately, the number of complaints against Russia shows that state bodies are not ready to fully implement the principles of the European Convention.

\title{
References
}

Case of Jehovah's Witnesses of Moscow v. Russia (2010), Available at: http://www.garant.ru/ products/ipo/prime/doc/12083552/\#ixzz4Iyl6k7cO (Accessed 01.03.2017)

Case of Böhmer v. Germany (2001), Available at: http://www.nullapoena.de/iur/boehmer.html (Accessed 12.03.2017)

Case of Moscow Branch of the Salvation Army v. Russia (2006), Available at: http://www.garant. ru/products/ipo/prime/doc/2466473 (Accessed 01.03.2017)

Case of Church of Scientology in Moscow v. Russia (2007), Available at: http://www.garant.ru/ products/ipo/prime/doc/2467581/ (Accessed 12.03.2017)

Case of Sergey Kuznetsov v. Russia (2008), Available at: http://www.garant.ru/products/ipo/ prime/doc/12067522/ (Accessed 12.03.2017)

Case of Khrabrova v. Russia (2012), Available at: http://base.garant.ru/70286716/ (Accessed 12.03.2017)

\section{Охрана прав и законных интересов человека Европейской конвенцией \\ в России и Германии}

\author{
А. Пушкина \\ Сибирский федеральный университет \\ Россия, 660041, Красноярск, пр. Свободный, 79
}

\begin{abstract}
Европейская конвенция по правам человека - это эффективное международное средство для зашиты основных прав и свобод человека в европейских странах. Конвенция вступила в силу 3 сентября 1953 года и должна быть ратифицирована всеми членами Совета Европь. Конвенция также учредила Европейский суд по правам человека. Цель данной работы - показать, как Европейский суд может охранять права человека. Ранее проведенные исследования и общепринятая практика показывают, что каждый считает, что может обратиться в суд и рассчитывать на его защиту. Автором были проанализированы некоторые дела Европейского суда против Германии и России и исследованы последствия их результатов. В завершение статьи были показаны возможности охраны прав человека Европейским судом. В иелом решения Европейского суда оказали влияние на изменение законодательства в России и Германии и на обеспечение прав и свобод. Таким образом, Европейский суд по правам человека действует не только репрессивно, но и превентивно.
\end{abstract}

Ключевые слова: охрана прав и свобод, Европейский суд по правам человека.

Научная специальность: 12.00.00 - юридические науки. 